\title{
PENGARUH STANDAR AKUNTASI PEMERINTAH TERHADAP KUALITAS LAPORAN KEUANGAN DI BADAN KEUANGAN DAERAH KABUPATEN BULELENG
}

\author{
I Gede Ariawan, Putu Indah Sonia Dewi, \\ Kiomang Artisya, Desak Putu Intan \\ Jurusan Akuntansi, Universitas Pendidikan Ganesha, Singaraja, Bali, Indonesia
}

\begin{abstract}
Abstrak
Penelitian ini bertujuan untuk mengetahui apa yang melatarbelakangi terbentuknya Standar Akuntansi Pemerintah, bagaimana dampak setelah diterapkannya Standar Akuntansi Pemerintah pada kualitas Laporan Keuangan Badan Keuangan Daerah di Kabupaten Buleleng, apa saja kendalakendala yang dihadapi dalam menyusun laporan keuangan berdasarkan Standar Akuntansi Pemerintah. Penelitian yang dilakukan menggunakan metode penelitian kualitatif. Proses analisis data dalam penelitian ini sudah melakukan obeservasi. Dengan demikian, standar akuntansi pemerintah merupakan persyaratan yang mempunyai kekuatan hukum dalam upaya meningkatkan kualitas laporan keuangan pemerintah di Indonesia. Dalam menyusun laporan keuangan adapun kendala yang dihadapi yaitu: Kualitas sumber daya manusia yang belum memadai, Struktur Organisasi, Aspek Regulasi, Aspek Sosialisasi dan Pendampingan, Ketiadaan sanksi, Kemauan.
\end{abstract}

Kata kunci: BKD, Standar,Kualitas

\section{Abstract}

This study aims to find out what lies behind the formation of Government Accounting Standards, how the impact after the adoption of Government Accounting Standards on the quality of the Financial Statements of Regional Financial Institutions in Buleleng Regency, what are the obstacles encountered in preparing financial statements based on Government Accounting Standards. Research conducted using qualitative research methods. The process of data analysis in this study has been observed. Thus, government accounting standards are a legal requirement in an effort to improve the quality of government financial reports in Indonesia. In preparing the financial statements, the constraints faced are: Inadequate quality of human resources, Organizational Structure, Regulatory Aspects, Socialization and Assistance Aspects, Absence of sanctions, Willingness.

Keywords : BKD, Standard, Quality

\section{Pendahuluan}

Akuntansi Pemerintahan dapat didefinisikan sebagai suatu aktivitas pemberian jasa untuk menyediakan informasi keuangan pemerintah berdasarkan proses pencatatan, pengklasifikasian, pengikhtisaran suatu transaksi keuangan pemerintah serta penafsiran atas informasi keuangan tersebut, (Bachti Arif, dkk, 2002:3). Selain itu menurut Abdul Halim (2002 : 143), menyebutkan bahwa akuntansi pemerintahan adalah sebuah kegiatan jasa dalam rangka menyediakan informasi kuantitatif terutama yang bersifat keuangan dari entitas pemerintah guna pengambilan keputusan ekonomi yang nalar dari pihak - pihak yang berkepentingan atas berbagai arternatif arah tindakan.

Tuntutan transparansi dan akuntabilitas atas dana - dana masyarakat yang dikelola pemerintah memunculkan kebutuhan atas penggunaan akuntansi dalam mencatat dan melaporkan kinerja pemerintah. Akuntansi pemerintahan sebenarnya mempunyai tiga tujuan pokok diantaranya yaitu ada pertanggung jawaban dimana akuntansi pemerintahan memberikan informasi keuangan yang lengkap, cermat, dan dalam bentuk dan waktu yang tepat yang berguna bagi pihak yang bertanggungjawab terkait kegiatan unit - unit pemerintahan. Lalu ada manajerial, dimana akuntansi pemerintahan juga harus menyediakan informasi keuangan yang diperlukan untuk perencanaan, penganggaran, pelaksanaan, pemantauan, pengendalian anggaran, rumusan kebijakan, pengambilan keputusan, dan penilaian kinerja pemerintah. Dan yang terakhir ada pengawasan, dimana 
akuntansi pemerintahan juga harus memungkinkan terselenggaranya pemeriksaan oleh aparat pengawasan fungsional secara efektif dan efisien. Namun karena adanya tuntutan transparansi dan akuntabilitas atas dana - dana masyarakat maka diperlukannya pembuatan laporan keuangan.

Menurut Harahap (2002:7), mengemukakan bahwa laporan keuangan adalah merupakan pokok atau hasil akhir dari suatu proses akuntansi yang menjadi bahan informasi bagi para pemakainya sebagai salah satu bahan dalam proses pengambilan keputusan dan juga dapat mengambarkan indikator kesuksesan suatu perusahaan mencapai tujannya. Dalam membuat laporan keuangan di pemerintahan, data - data yang disajikan harus sesuai dengan standar akuntansi pemerintahan. Standar Akuntansi Pemerintahan diperlukan sebagai pedoman umum yang diperlukan dalam rangka mewujudkan konsolidasin fiskal dan statistik keuangan pemerintah secara nasional.

Selain itu penelitian yang menguji pengaruh penerapan akuntansi pemerintah terhadap kualitas laporan keuangan dilakukan Susilawati dan Riana (2014) yang menyatakan bahwa standar akuntansi pemerintah (SAP) berpengaruh positif terhadap laporan keuangann daerah,

Berdasarkan permasalahan diatas, adapun rumusan masalah yang dilakukan yaitu untuk mengetahui apa yang melatarbelakangi terbentuknya Standar Akuntansi Pemerintah, bagaimana dampak setelah diterapkannya Standar Akuntansi Pemerintah pada kualitas Laporan Keuangan Badan Keuangan Daerah di Kabupaten Buleleng, apa saja kendalakendala yang dihadapi dalam menyusun laporan keuangan berdasarkan Standar Akuntansi Pemerintah.

\section{Metode}

Penelitian yang dilakukan menggunakan metode penelitian kualitatif. Sebagaimana dikutip oleh Moeleong (2012 : 4), Bogdan dan Taylor (1975) mendefinisikan metodologi penelitian kualitatif sebagai prosedur penelitian yang menghasilkan data deskriptif berupa kata - kata tertulis atau lisan dari orang - orang dan perilaku yang sedang diamati. Penelitian ini termasuk ke dalam penelitian kualitatif dikarenakan penelitian yang dilakukan secara holistik, sarat dengan makna karena berhubungan dengan kenyataan yang ada di situs penelitian, serta berasal dari kata - kata ataupun tingkah laku para informan.

Pemilihan lokasi penelitian merupakan langkah umum yang wajib dilakukan pertama kali oleh para peneliti kualitatif. Tanpa situs atau lokasi yang jelas penelitian mustahil untuk dilakukan. Penelitian ini dilakukan di Badan Keuangan Daerah (BKD) Kabupaten Buleleng. Alasan peneliti memilih BKD Kabupaten Buleleng yaitu karena BKD merupakan salah satu instansi pemerintahan Dearah yang tentunya pasti mengikuti kebijakan pemerintah. Selain itu BKD Kabupaten Bulelng juga telah menerapkan Standar Akuntansi pemerintahan (SAP).

Proses analisis data dalam penelitian ini sudah melakukan obeservasi. Analisis dilakukan dengan memahami perilaku atau tindakan para informan dalam aktivitas sehari harinya serta melakukan komunikasi langsung dengan para informan.

\section{Hasil dan Pembahasan}

\section{Latar belakang Terbentuknya Standar Akuntansi Pemerintah}

Berdasarkan peraturan Pemerintah Nomer 71 Tahun 2010, definisi Standar Akuntansi Pemerintah, yang selanjutnya disingkat SAP, adalah prinsip - prinsip akuntansi yang diterapkan dalam menyusun dan menyajikan laporan keuangan pemerintah. Dapat disimpulkan bahwa standar akuntansi pemerintah (SAP) merupakan persyaratan yang mempunyai kekuatan hukum dalam upaya meningkatkan kualitas laporan keuangan pemerintah di Indonesia. Standar Akuntansi Pemerintah (SAP) meupakan standar akuntansi pertama di Indonesia yang mengatur mengenai akuntansi pemerintah di Indonesia. Sehingga dengan adanya standar akuntansi ini, maka laporan keuangan pemerintah yang merupakan hasil dari proses akuntansi diharapkan dapat digunakan sebagai alat komunikasi antara pemerintah dengan stakeholders sehingga tercipta pengelolaan keuangan negara yang transparan dan akuntabel. Standar Akuntansi Pemerintah merupakan pedoman untuk 
menyatukan presepsi antara penyusun, pengguna dan auditor. Pemerintah pusat dan juga pemerintah daerah wajib menyajikan laporan keuangan sesuai dengan standar akuntansi pemerintah (SAP). Pengguna laporan keuangan termasuk legislatif akan menggunakan SAP untuk memahami informasi yang disajikan dalam laporan keuangan dan eksternal auditir (BPK) akan menggunakannya sebagai kriteria dalam pelaksanaan audit.

Menurut sumber yang kami wawancarai yaitu Ketua Badan Keuangan Daerah (BKD) Kabupaten Buleleng, beliau mengatakan bahwa diterapkannya Standar Akuntansi Pemerintah (SAP) di Badan Keuangan Daerah tersebut berkaitan dengan kebijakn pemerintah Indonesia yaitu pemerintah Indonesia telah melakukan reformasi di bidang akuntansi, salah satunya yaitu keharusan penerapan standar akuntansi pemerintahan di instansi pemerintah baik pemerintah pusat maupun pemerintah daerah. Pihaknya juga menuturkan bahwa penerapan Standar Akuntansi Pemerintahan (SAP) tersebut mulai diterapkan pada tahun anggaran 2008.

\section{Dampak Setelah Diterapkannya Standar Akuntansi Pemerintah pada kualitas Laporan Keuangan Badan Keuangan Daerah di Kabupaten Buleleng}

Peraturan Pemerintah Nomor 71 Tahun 2010 tentang Standar Akuntansi Pemerintah (SAP) merupakan prinsip - prinsip akuntansi yang diuterapkan dalam menyusun dan menyajikan laporan keuangan pemerintah. Dengan demikian, standar akuntansi pemerintah merupakan persyaratan yang mempunyai kekuatan hukum dalam upaya meningkatkan kualitas laporan keuangan pemerintah di Indonesia. Pemerintah menerapkan Standar Akuntansi Pemerintah dalam menyusun dan menyajikan laporan keuangan. Dalam hal itu laporan keuangan memiliki dua basis yaitu Standar Akuntansi Pemerintah (SAP) berbasis akrual dan Standar Akuntansi Pemerintah (SAP) berbasis kas menuju akrual.

Penerapan Standar Akuntansi Pemerintah (SAP) berbasis akrual dalam lingkungan pemerintahan adalah untuk mengetahui seberapa besarnya biaya yang diperlukan untuk menghasilakan pelayanan untuk kepentingan publik, serta menentukan harga pelayanan yang dibebankan kepada publik. Dengan adanya standar akuntansi pemerintah (SAP) berbasis akrual maka dapat menghasilkan informasi keuangan berupa laporan keuangan pemerintah daerah yang bersifar relefan, andal, dapat dibandingkan, dan dapat dipahami untuk mengambilan suatu keputusan baik ekonomi, sosial, maupun politik.

Suatu pemerintah yang menerapkan standar akuntansi pemerintahan akan menghasikan laporan keuangan yang sangat diperlukan dalam lingkungan pemerintahan. Dengan standar akuntansi pemerintahan diharapkan agar semua berjalan, tersruktur dan sesuai dengan pedoman yang berlaku sehingga akan menghasilkan laporan keuangan yang berkualitas dan akurat terutama laporan keuangan yang keberadaannya sangat penting dan dibutuhkan untuk dipertanggung jawabkan.

\section{Kendala-kendala yang Dihadapi Dalam Menyusun Laporan Keuangan Berdasarkan Standar Akuntansi Pemerintah}

Ada beberapa kendala yang dihadapi oleh pemerintah daerah dalam penerapan Standar Akuntansi Pemerintah (SAP) khususnya di Badan Keuangan Daerah Kabupaten Daerah. Menurut pendapat Bapak Bimantara selaku kepala Badan Keuangan Daerah Buleleng mengungkapkan bahwa kendala yang dihadapi dalam menyusun laporan keuangan yaitu:

1. Kualitas sumber daya manusia yang belum memadai

Persoalan ini sangat mendasar, dimana kita mengingat perekrutan PNS (Pegawai Negeri Sipil) yang masih terpusat. Meskipun kewenangan untuk pelaksanaan program peningkatan kualitas Sumber Daya Manusian ada di daerah. Pemekaran daerah menjadi persoalan yang sangat penting karena ketika sumber daya manusia yang terbatas yang kemudian harus di bagi lagi

2. Struktur Organisasi

3. Sesuai dengan peraturan pemerintah Nomer 41 Tahun 2007 pemerintah daerah sudah harus menyusun struktur organisasi baru dimana ruang untuk akuntansi semakin 
terbuka. Namun rendahnya kualitas dan kuantitas Sumber Daya Manusia akuntansi menjadi persoalan yang kian berat.

4. Aspek Regulasi

Ketidak konsistensian dalam penerbitan peraturan perundangan yang terkait dengan akuntansi pemerintahan mengakibatkan pemerintah daerah kehilangan selera untuk melaksanakan akuntansi dimana akuntansi daerah dijadikan objek penderita karena ada beberapa petunjuk teknis atau pedoman pelaksanaan yang tidak sejalan. Misalnya antara kemendagri nomer 13 Tahun 2006 dengan peraturan pemerintah nomer 24 tahun 2005 belum lagi antara peraturan pemerintah nomer 24 tahun 2005 dengan undang - undang nomer 17 tahun 2003. Sebagai jalan tengah Depdagri menerbitkan surat edaran yang diantaran menjelaskan proses konversi dari kemendagri nomer 13 tahun 2006 keperaturan pemerintah nomer 24 tahun 2005.

5. Aspek Sosialisasi dan Pendampingan

Sosialisasi oleh depdagri, KSAP, BPK, dan pihak - pihak lain yang telah berjalan yang masih di rasa sangat kurang. Dalam hal ini soal pendanaan merupakan masalah utama. Dan kurangnya sosialisasi dari Pemerintah Pusat kepada Pemerintah Daerah, selain itu pula pemerintah daerah memerlukan pendampingan yang tepat untuk melakukan peneran Standar Akuntansi Pemerintah.

6. Ketiadaan sanksi

Memang sampai saat ini belum ada sanski kepada pemerintah daerah yang tidak menerapkan Standar Akuntansi Pemerintah sehingga BPK (Badan Pemeriksa Keuangan) selaku auditor tak jarang diminta oleh Pemerintah Daerah menjadi konsultan atau membantu menyusun laporan keuangan pemerintah daerah.

7. Kemauan

Dalam hal ini, kemauan lah yang sangat penting. Karena jika tidak ada kemauan dalam menerapkan Standar Akuntansi Pemerintah maka tidak akan di susunnya laporan keuangan sesuai dengan standar akuntansi pemerintah. Apalagi tidak adanya sanski dalam pembuatan yang tidak menggunakan standar akuntansi pemerintah.

\section{Simpulandan Saran Simpulan}

Berdasarkan pembahasan dan hasil penelitian di atas dapat disimpulkan bahwa Akuntansi Pemerintahan dapat didefinisikan sebagai suatu aktivitas pemberian jasa untuk menyediakan informasi keuangan pemerintah berdasarkan proses pencatatan, pengklasifikasian, pengikhtisaran suatu transaksi keuangan pemerintah serta penafsiran atas informasi keuangan tersebut, (Bachti Arif, dkk, 2002:3). .

Standar Akuntansi Pemerintah (SAP) meupakan standar akuntansi pertama di Indonesia yang mengatur mengenai akuntansi pemerintah di Indonesia. Sehingga dengan adanya standar akuntansi ini, maka laporan keuangan pemerintah yang merupakan hasil dari proses akuntansi diharapkan dapat digunakan sebagai alat komunikasi antara pemerintah dengan stakeholders sehingga tercipta pengelolaan keuangan negara yang transparan dan akuntabel. Dengan demikian, standar akuntansi pemerintah merupakan persyaratan yang mempunyai kekuatan hukum dalam upaya meningkatkan kualitas laporan keuangan pemerintah di Indonesia.

Dalam menyusun laporan keuangan adapun kendala yang dihadapi yaitu: Kualitas sumber daya manusia yang belum memadai, Struktur Organisasi, Aspek Regulasi, Aspek Sosialisasi dan Pendampingan, Ketiadaan sanksi, Kemauan

\section{Saran}

1. Bagi Penulis

Diharapkan penulis lebih mampu mengembangkan materi yang ada, dengan menambahkan dari referensi lain yang terpercaya.

2. Bagi Pembaca

Diharapkan pembaca mampu untuk melengkapi materi yang dipaparkan dengan bantuan dari referensi yang dipercaya. 
3. Bagi Pemerintah

Diharapkan pemerintah mampu untuk mengapresiasi karya anak bangsa dalam bentuk makalah ini.

\section{DaftarPustaka}

Ali, utsman. 2015. Pengertian Kualitas Menurut Pakar. Diunduh tanggal 10 Januari 2019. www.pengertianpakar.com/2015/pengertian-kualitas-menurut-pakar.html

Botutihe, Tutun Hermawanto, 2013. "Pengaruh Penerapan Sistem Akuntansi Keuangan Daerah Terhadap Kualitas Laporan Keuangan Pemerintah Kota Gorontalo". Skripsi. Universitas Neeri Gorontalo

Halim, Abdul. 2007. Pengelolaan Keuangan Daerah. UPP STIM YKPPN. Yogyakarta

Noviyanti. 2015. Pengertian, Tujuan, Jenis-jenis, dan Karakteristik Kualitatif Laporan Keuangan. Diunduh taanggal 10 Januari 2019. https://www.bagi-in.com/laporankeuangan/

Utami, Novia Widya. 2017. Pengertian Akuntansi dan Standar Akuntansi Pemerintah. Diunduh tanggal 10 Januari 2019. https://www.jurnal.id/id/blog/2017-pengertianakuntansi-dan-standar-akuntansi-pemerintah/ 